\title{
Investigation of the Genetically Modified Organism (GMO) Existence in Baby Foods on the Market in Turkey
}

\author{
Erdem Artuvan ${ }^{1, a, *}$, Salih Aksay ${ }^{2, b}$ \\ ${ }^{1}$ Mersin Food Control Laboratory Directorate, Gazi Mh. 1314 St. No:9 33130 Mersin, Turkey \\ ${ }^{2}$ Food Engineering Department, Mersin University, 33110 Mersin, Turkey
}

*Corresponding author

\begin{tabular}{l|l}
\hline A R T I C L E I N F O & A B S T R A C T \\
\hline Research Article & $\begin{array}{l}\text { It is called Organism Genetically Modified Organism (GMO) which is obtained by biotechnological } \\
\text { methods to modify the genetic sequences of living things, to improve their existing properties and / } \\
\text { or to gain new features. Baby milk and baby continue milk, which the babies consume during their } \\
\text { first month of the life, can also contain products such as soy, corn, rice according to their derivatives. } \\
\text { It is thought that GMO screening should also be done in baby formulas that contain these components } \\
\text { which are extensively produced in the genus modified organism class in the world. In this study, in } \\
\text { Accepted : } 25 / 10 / 2021\end{array}$ \\
$\begin{array}{l}\text { carbohydrates, protein analysis and real time PCR GMO screening was conducted. As a result of the } \\
\text { GMO scan, no product containing the p35S, tNOS and pFMV isomers was found. }\end{array}$
\end{tabular}

Keywords:

GMO

Baby Milk

Follow on formula

Real Time PCR

Food Safety

Türk Tarım - Gıda Bilim ve Teknoloji Dergisi, 9(10): 1945-1952, 2021

\section{Türkiye'de Piyasaya Sunulan Bebek Mamalarında Genetiği Değiştirilmiş Organizma (GDO) Varlığının Araştırılması}

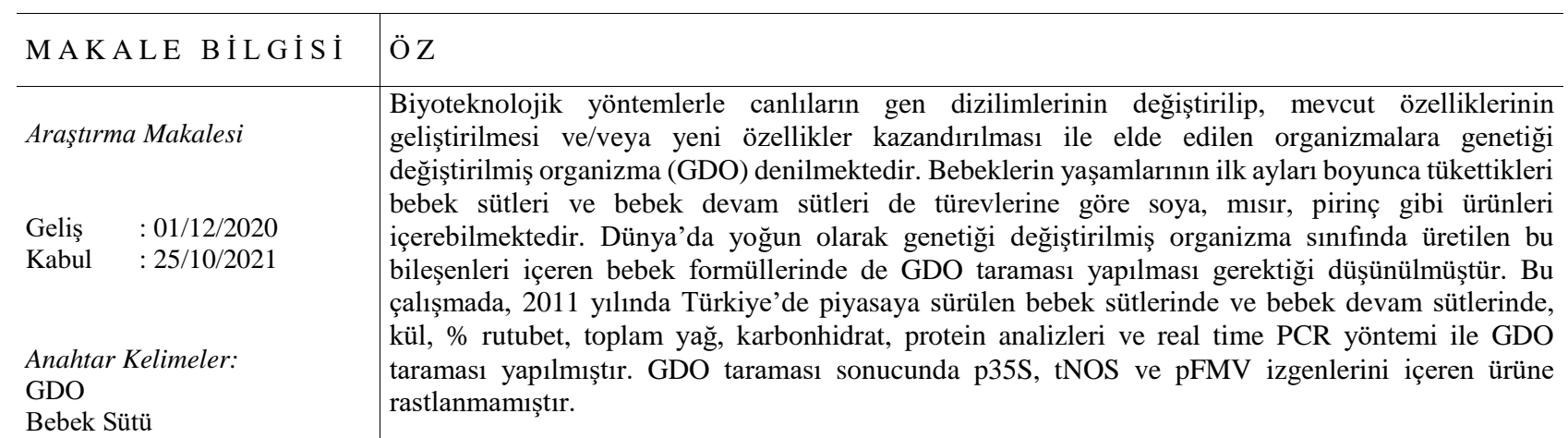

Devam Formülü

Gerçek Zamanlı PZR

Gıda Güvenliği

a@erdem_artuvan@yahoo.com $\quad$ (i) https://orcid.org/0000-0001-7318-0514_ b saksay@mersin.edu.tr (iD)https://orcid.org/0000-0002-6068-6628




\section{Introduction}

Compared to the production of GMO products, which are becoming widespread every day worldwide, the knowledge in the society does not increase at the same rate. It is an undeniable fact that, apart from a few individuals and organizations that are experts on the subject, the perception that occurs when the word "product with GMO" is used in the vast majority that consumes or is likely to consume these products is the same as the perception formed with the words "pesticide, hormone, poison etc.". The lack of public information about the existence, number and results of official controls on GMO, as well as the lack of information or pollution of the public as a result of the fact that the right or wrong predictions come to the fore, necessitated the continuation of new studies.

Baby foods, which are the first foods of humans, carry the risk of containing GMO products due to the components such as maize, soy, rice, etc. Considering the scarcity of published scientific articles on GMO analysis in baby foods, the need has been made to identify the general composition of these products and to screen for the presence / absence of GMO.

During the first months of babies' lives, ready-to-eat foods that meet their special nutritional needs until they meet proper complementary nutrition, are called baby food or infant formula, with no need for any action other than adding water (Resmi Gazete, 2014a). The formulas that babies can get from the time they are born are called "Baby Formula", and the foods that they can consume after the 6th month are called "Continued Formula". According to the Turkish Food Codex, the "Continued Formula" is constitutes the main fluid intake of babies from six months onwards, since a different month is not recommended based on the growth and development needs of the baby, by a neutral health worker specializing only on mother and child nutrition, with the purpose of special nutrition (Resmi Gazete, 2014b).

Baby food is a synthetic version of breast milk, designed to meet the daily nutritional needs of the baby. These products consist of mixtures of fats, proteins, carbohydrates and other nutrients such as minerals closest to natural nutrients with commercially suitable methods. In addition, special formulas may contain soy proteins for individuals with low milk protein tolerance (Table 1) (Anonymous, 2013a; Morales and Olano, 2004; Nasirpour et al., 2006; Alvares et al., 2005; McCarthy and Gee, 2013; Abdel-Selam et al., 2013).

Table 1. The main components of baby formulas (Nasirpour et al., 2006)

\begin{tabular}{l|l}
\hline Food Ingredients & Component Resources \\
\hline Protein content & $\begin{array}{l}\text { Skimmed milk powder, skimmed milk, demineralized whey, Sodium and Calcium } \\
\text { Caseinate, soy protein and pure soy milk } \\
\text { Soy, maize, saffron, sunflower, rapeseed, palm kopra } \\
\begin{array}{l}\text { Fat content } \\
\text { Mineral content } \\
\text { Major }\end{array}\end{array}$ \\
$\begin{array}{l}\text { Lactose, starch, sucrose, maize syrup and corn syrup solids } \\
\text { Calcium carbonate, mono-, di- and tribasic calcium phosphate, dibasic magnesium } \\
\text { phosphate, potassium citrate, magnesium chloride }\end{array}$ \\
$\begin{array}{l}\text { Potamins } \\
\text { Functional components }\end{array}$ & $\begin{array}{l}\text { A, E, K, C, B1, B2, B6, B12, niacin, folic acid, pantothenic acid, biotin, choline, inositol } \\
\text { Soy lecithin, mono- and diglycerides, starch, carrageenan }\end{array}$ \\
\hline
\end{tabular}

Individuals who cannot tolerate formulas based on cow's milk, soy protein, or hydrolysed protein prefer Amino Acid-Based formulas. Amino acid-based formulas are only available in powder form on the market. These formulas contain maize syrup solids, free amino acids and vegetable oil mixtures as a major nutrient component. (Nasirpour et al., 2006; Alpsan, 2008).

Formulas based on soy protein are available on the market in powder, concentrate or liquid form ready for consumption. These formulas may be suitable for individuals who cannot consume cow's milk and have low lactose tolerance. In soy-based formulas, protein levels are generally much higher than cow's milk due to the high digestibility of soy proteins and differences in amino acid composition. Baby foods, biscuits, cakes, puddings, candies, chocolates, waffles and instant soups containing genetically modified soy and / or maize products; however, it falls into the risky group, such as foods made from chickens that contain corn and soy in the feed and consume them. (Nasirpour et al., 2006; Li and Zhu, 2011; Çelik and Balık, 2007).

Genetically modified organisms started to be produced commercially in the area of 1.7 million hectares in 1996 and the area of production in the past 21 years has reached 189.8 million hectares in 2017 (Park and Lee, 2010;
Anonymous 2013b, 2013; Borchers and Teuber, 2010; Nardalı and Kartal, 2005; James, 2018).

Discussions continue about the production and commercial use of genetically modified products. Controlled production continues in some places in the UK, although the European Union does not stay close to these studies because it is afraid of public reactions. In addition, GD product production for small scale trials continues in countries such as Bulgaria, Germany, Romania and France (Kulaç and Ağırdil, 2006).

Consumers' thoughts about genetically modified products differ according to the knowledge and education level of the society, moreover, many different reactions can occur in many parts of the world (Özdemir and Duran, 2010).

In a GMO production process, the steps of 1. Finding the desired genes, 2. Characterization, 3. Isolation and 4. Transfer to the target species are carried out respectively. The essence of GMO technology is the transformation of plant DNA by transplanting the gene region with the desired properties from another source (microorganism) and creating the preferred feature. Normally, such genetic manipulations on the plant are performed not only by transferring a single feature, but by transplanting a particular gene chain. This chain consists of a structure 
called the promoter gene, which gives the plant the desired property, and terminator and marker genes.

Gene transfer through Agrobacterium is the most widely used method. The fact that this bacterium has the Ti plasmid that causes stem cell tumour as well as chromosome DNA has made it a genetic engineer. In this method, the DNA fragment carrying the gene to be transferred to the plant is replaced with the T-DNA region cutting enzymes, and this DNA fragment can be transferred to plant cells due to the nature of bacteria (Kaya and Karakoç, 2010; Ahmed, 2002).

Apart from gene transfer with Agrobacterium, transfer methods such as gene transfer with particle gun, direct gene transfer with protoplasts are also used (Kaya and Karakoç, 2010, Ahmed, 2002).

The presence of modified genes in raw products and processed products can be understood by the method of determining the presence of the added DNA or by the presence of the protein formed after insertion. The basis of protein-based analysis methods used in the analysis of genetic modified products is the specific detection of new proteins encoded by certain genes. These analysis methods are limited to fresh and unprocessed foods as a matrix as they require proteins with full conformation and are not denatured (Kaya and Karakoç, 2010; Ahmed, 2002; Kıran and Osmanağaoğlu, 2011).

Protein-based analysis methods can be listed as immunoassay method, ELISA method, Lateral Flow Strip Method and Westerns Blot Method. Southern Blot Method and PCR (Polymerase Chain Reaction) methods and nucleic acid based methods. The PCR method was first described by Kary Mullis et al in 1985 and used in molecular biological applications. The PCR process is the natural copying process of the DNA molecules that occurs in the cellular organism in vitro (Kaya and Karakoç, 2010; Ahmed, 2002; Gryson, 2010; Gaudio and Cirillo, 2010).

\section{Material and Method}

\section{Material}

In the study, baby milk and baby continued milk, which are likely to contain genetically modified soy, maize and / or cereal, were selected as the material. In 2011, the baby milk (baby formula) and baby continued milk samples were taken from the market and the analyses listed below were made. Samples are coded from A to J. Parallel studies in the analyses are separated by numbers $1,2,3$. It was studied in a total of 10 samples. When calculating the nutritional composition values of each sample, the dilution rates stated on the label were used. Dilution rate of the samples are given in Table 2.

According to the Turkish Food Codex Baby Formulas Communiqué, the Baby Formula defines products that meet special nutritional needs during the first months of babies' lives until they meet proper complementary nutrition.

According to the Turkish Food Codex Continuance Formula Communiqué, Continued Formula is the main fluid intake in infants' diets from six months, unless a different month is recommended for a special diet based on the growth and development needs of the baby, only by a neutral health worker who specializes in mother and child nutrition. defines the products that make up.
Table 2. Dilution rate of the samples

\begin{tabular}{c|c}
\hline Sample Code & Dilution Rate $(\mathrm{g} / 100 \mathrm{ml})$ \\
\hline A & 14.0 \\
B & 14.6 \\
C & 14.0 \\
D & 14.0 \\
E & 14.0 \\
F & 14.0 \\
G & 16.0 \\
H & 16.0 \\
I & 13.7 \\
J & 14.0 \\
\hline
\end{tabular}

Protein, fat, carbohydrate, ash and moisture analyzes were carried out to determine and define the general characteristics of the samples and GMO Screening Analysis was carried out to determine the presence of GMO.

\section{Method}

Determination of Moisture Content

As stated in TS 11729 (1995); $5 \mathrm{~g}$ of sample was weighed, held in a $105^{\circ} \mathrm{C}$ oven overnight until constant weighing and moisture content was determined from the difference between the first and last masses of the sample (TS 11729, 1995).

\section{Ash Analysis}

Analysis was made according to TS 1511 ISO 2171 October 2000 Cereals and Ground Grain Products - Total Ash Content Determination standard (TS 1511, 2000).

\section{Protein Analysis}

According to the AOAC Method 992.23, nitrogen determination was made in LECO FP 528 Automatic device. 0.15-0.30 g sample weighed into gel capsule and read from device (Anonymous, 2000).

\section{Determination of Fat}

It was made according to TS 4967 (1986).

Carbohydrate Determination

The analysis was carried out according to TS 11729 (1995).

\section{Energy Calculation}

Energy was calculated using the formula below according to the "Turkish Food Codex Labeling Regulation" (Turkish Food Codex, 2011).

$$
\begin{aligned}
\text { Energy }(\mathrm{kcal} / \mathrm{g}) & =9 \times \text { Fat Energy }+4 \times \text { Protein Energy } \\
& +4 \times \text { Carbohydrates Energy }
\end{aligned}
$$

\section{GMO Screening Analysis}

The analysis was carried out in 3 stages.

In the first stage, the pre-extraction process of the sample was done according to the preparation kit produced by Biotecon company. At this stage, the lysis buffer and Proteinase $\mathrm{K}$ are aimed to disintegrate the vegetative tissue cell. DNA isolation was done using the Magna Pure Compact Nucleic Acid Isolationon Kit 1 (Cat.No. 03730 964 001) method using MagnaPure Compact automatic isolation device. At the end of this process, sufficient concentration and purity DNA was tried to be obtained for the analysis (Roche, 2007). 
In the second stage, DNA was obtained according to the GMO Screening Kit (BIOTECON Diagnostics Catalog No: R 302 17) method; enriched with primers, enzymes, buffers and dNTPs (Biotecon, 2010).

The third stage is the Real Time PCR stage. The process is based on a series of chain reactions involving the breaking of DNA chains replicated at the appropriate temperature at high temperature. The presence/absence of GMO in the samples was determined as a result of this analysis (Biotecon, 2010).

\section{Statistical Analysis}

In the product nutrient components analysis results, One Way Variance (ANOVA) test was applied in 95\% confidence interval and it was examined whether there was a significant difference with the Tukey test.

\section{Results and Discussion}

\section{Moisture, Ash, Protein, Fat and Carbohydrate Analysis Results}

In order to determine the general characteristics of the samples, moisture, ash, energy, total fat, protein and carbohydrate analyses were done and the results of total fat, protein and carbohydrate calculated on $100 \mathrm{~g}$ sample basis are given in Table 3.

The energy value has been calculated in order to match the results to the units in the Baby Formulas and Baby Continuance Formulas communiqués. Total fat, protein and carbohydrate results are determined on the basis of energy. Each analysis was run in 3 parallel. Average results and standard deviation values of these analyses are given in Table 4.

In moisture (\%) analysis, the results were between $0.03031 \pm 0.0065$ and $0.5032 \pm 0.0388$. In ash (\%) analysis, the results were between $0.2132 \pm 0.0093$ and $0.3146 \pm$ 0.0007 . In the energy analysis, the results were between $64.1181 \pm 0.2654 \mathrm{kcal} / 100 \mathrm{ml}$ and $70.3268 \pm 0.0323 \mathrm{kcal}$ / $100 \mathrm{ml}$. In total fat analysis, the results were between $4.6471 \pm 0.0524 \mathrm{~g} / 100 \mathrm{kcal}$ and $5.9333 \pm 0.0084 \mathrm{~g} / 100$ $\mathrm{kcal}$. In protein analysis, the results were between 1.6728 $\pm 0.0008 \mathrm{~g} / 100 \mathrm{kcal}$ and $2.1292 \pm 0.0148 \mathrm{~g} / 100 \mathrm{kcal}$. In carbohydrate analysis, the results were in the range of $9.6763 \pm 0.0266 \mathrm{~g} / 100 \mathrm{kcal}$ and $12.5784 \pm 0.0187 \mathrm{~g} / 100$ kcal. The difference between the results was found statistically significant $(\mathrm{P}<0.05)$.

\section{GMO Screening Analysis Results}

The DNA extraction kit and protocol produced by Biotecon Company specific to vegetable foods were used. With the extracts obtained, DNA isolation process was initiated by using the MagNa Pure Compact automatic isolation device and the appropriate kit. DNA concentration and quality of isolates obtained after isolation were measured by spectrophotometer. DNA concentration (ng / $\mu \mathrm{L}$ ) and DNA quality (OD 260/280) values are given in Table 5.

Table 3. Analysis results on a $100 \mathrm{~g}$ sample basis

\begin{tabular}{c|cc}
\hline Total Fat $(\mathrm{g} / 100 \mathrm{~g})$ & Protein $(\mathrm{g} / 100 \mathrm{~g})$ & Carbohydrate $(\mathrm{g} / 100 \mathrm{~g})$ \\
\hline 29.6761 & 9.4369 & 56.2355 \\
32.0974 & 9.0492 & 53.9754 \\
23.6480 & 10.6892 & 61.6083 \\
22.9179 & 11.4733 & 60.2638 \\
23.0592 & 9.7179 & 62.3791 \\
25.9605 & 9.7029 & 58.4459 \\
31.2343 & 11.1973 & 52.9978 \\
31.9843 & 10.7631 & 52.2393 \\
24.8490 & 10.6944 & 59.9985 \\
26.4470 & 10.5590 & 57.0531 \\
\hline
\end{tabular}

Table 4. Moisture (\%), Ash (\%), Energy, Total Fat, Protein and Carbohydrate Analysis Results

\begin{tabular}{|c|c|c|c|c|c|c|}
\hline \multirow[b]{2}{*}{$\begin{array}{l}\text { Legal } \\
\text { Limits }\end{array}$} & \multirow[b]{2}{*}{ Moisture \% } & \multirow[b]{2}{*}{ sh $\%$} & $\begin{array}{c}\text { Energy (kcal/100 } \\
\text { ml) }\end{array}$ & $\begin{array}{l}\text { Total Fat }(\mathrm{g} / 100 \\
\text { kcal) }\end{array}$ & $\begin{array}{l}\text { Protein }(\mathrm{g} / 100 \\
\mathrm{kcal})\end{array}$ & $\begin{array}{l}\text { Carbohydrate } \\
(\mathrm{g} / 100 \mathrm{kcal})\end{array}$ \\
\hline & & & $60<x<70$ & $\begin{array}{l}4.4<x<6 \\
4.0<x^{1}<6\end{array}$ & $\begin{array}{l}1.80<x<3.00 \\
1.80<x^{1}<3.50 \\
2.13<x^{2}<2.33\end{array}$ & $9<x<14$ \\
\hline Samples & \multicolumn{6}{|c|}{ Analysis Results } \\
\hline A & $0.3819 \pm 0.00850 .2228 \pm$ & 00025 & $68.8707 \pm 0.0300$ & $5.6017 \pm 0.0065$ & $1.7813 \pm 0.0139$ & $10.6150 \pm 0.0025$ \\
\hline $\mathrm{B}^{1}$ & $0.3968 \pm 0.01850 .2373 \pm$ & 0.0137 & $70.3268 \pm 0.0323$ & $5.9333 \pm 0.0084$ & $1.6728 \pm 0.0008$ & $9.9774 \pm 0.0183$ \\
\hline $\mathrm{C}^{2}$ & $0.3069 \pm 0.00840 .2202 \pm$ & 0.0108 & $65.2629 \pm 0.0509$ & $4.7106 \pm 0.0059$ & $2.1292 \pm 0.0148$ & $12.2720 \pm 0.0273$ \\
\hline $\mathrm{D}^{1 / 2}$ & $0.4198 \pm 0.09110 .2751 \pm$ & 0.0021 & $64.1181 \pm 0.2654$ & $4.6471 \pm 0.0524$ & $2.3263 \pm 0.0081$ & $12.2178 \pm 0.1257$ \\
\hline $\mathrm{E}$ & $0.4165 \pm 0.01870 .2132 \pm$ & 0.0093 & $64.4698 \pm 0.0746$ & $4.6498 \pm 0.0119$ & $1.9596 \pm 0.0186$ & $12.5784 \pm 0.0187$ \\
\hline $\mathrm{F}^{1}$ & $0.5032 \pm 0.03880 .2626 \pm$ & 0.0037 & $65.8113 \pm 0.0994$ & $5.1282 \pm 0.0236$ & $1.9167 \pm 0.0144$ & $11.5449 \pm 0.0542$ \\
\hline G & $0.3031 \pm 0.00650 .2911 \pm$ & 0.0342 & $69.9256 \pm 0.1439$ & $5.8069 \pm 0.0140$ & $2.0817 \pm 0.0117$ & $9.8528 \pm 0.0386$ \\
\hline $\mathrm{H}^{1}$ & $0.3473 \pm 0.00990 .3045 \pm$ & 0.0074 & $70.1829 \pm 0.0526$ & $5.9245 \pm 0.0091$ & $1.9937 \pm 0.0063$ & $9.6763 \pm 0.0266$ \\
\hline I & $0.3239 \pm 0.00070 .2557 \pm$ & 0.0015 & $65.8336 \pm 0.0035$ & $4.9069 \pm 0.0003$ & $2.1118 \pm 0.0021$ & $11.8478 \pm 0.0026$ \\
\hline $\mathrm{J}^{1}$ & $0.4578 \pm 0.00350 .3146 \pm$ & 0.0007 & $66.1013 \pm 0.0069$ & $5.2013 \pm 0.0018$ & $2.0766 \pm 0.0102$ & $11.2205 \pm 0.0134$ \\
\hline
\end{tabular}


Table 5. DNA Concentration and DNA Quality Values

\begin{tabular}{l|cccc}
\hline Sample Code & $\begin{array}{c}\text { DNA Concentration } \\
(\mathrm{ng} / \mu \mathrm{L})\end{array}$ & $\begin{array}{c}\text { DNA quality } \\
(\text { OD 260/280) }\end{array}$ & $\begin{array}{c}\text { Plant Genes } \\
\text { CT Values }\end{array}$ & $\begin{array}{c}\text { IC CT } \\
\text { Values }\end{array}$ \\
\hline A1 & 1.83 & 1.83 & 36.32 & 34.22 \\
A2 & 1.27 & 1.43 & 36.06 & 34.13 \\
B1 & 21.15 & 1.53 & 35.96 & 33.58 \\
B2 & 38.14 & 1.45 & 35.62 & 33.82 \\
C1 & 3.68 & 1.46 & 37.37 & 34.20 \\
C2 & 3.38 & 1.26 & 37.40 & 33.54 \\
D1 & 4.04 & 1.44 & 35.25 & 34,47 \\
D2 & 2.97 & 1,46 & 36,89 & 33.63 \\
E1 & 2.57 & 1.53 & 35.22 & 34.22 \\
E2 & 4.33 & 1.79 & 36.18 & - \\
F1 & 8.82 & 1.83 & 21.86 & - \\
F2 & 5.36 & 2.09 & 22.28 & 33.72 \\
G1 & 8.33 & 1.38 & 37.55 & 34.16 \\
G2 & 4.69 & 2.00 & 37.27 & 34.25 \\
H1 & 6.76 & 2.01 & 40.42 & 33.64 \\
H2 & 3.62 & 2.18 & 38.72 & 33.31 \\
I1 & 4.2 & 1.49 & 31.58 & 33.32 \\
I2 & 8.34 & 1.29 & 32.40 & 33.93 \\
J1 & 5.13 & 2.05 & 30.16 & 37.09 \\
J2 & 4.86 & 1.84 & 30.68 & - \\
CRM & - & - & 17.98 & 34.50 \\
PK & - & - & 28.98 & 33.37 \\
EB & - & - & - & 32.94 \\
NK & - & - & & \\
\hline
\end{tabular}

The samples whose DNA quality was measured were mixed with master mix solutions in appropriate volumes for enrichment before polymerase chain reaction (PCR). An analysis kit prepared by Biotechon for the detection of p35s, tNOS, pFMV and BAR trace genes was applied. In accordance with the GMO screening analysis protocol, the sample known as positive (CRM), plant gene-free sample (NK), environmental contamination control sample (EB) and positive PCR control sample (PK) were also included as control parameters.

As a result of the screening for $\mathrm{p} 35 \mathrm{~S}$, tNOS, and $\mathrm{pFMV}$ genes, which are the target genes (trace gene), only amplification were observed in CRM and PK DNA. CT value of $\mathrm{p} 35 \mathrm{~S}$ gene in CRM DNA is 24.38; The CT value of the p35S gene in PK DNA has been determined as 26.44 . Amplification in the tNOS gene was observed in the environmental contamination control sample (EB). CT value of the tNOS gene in CRM DNA is 24.82; CT value in PK DNA is 27.65; The CT value of the amplification under the control of $\mathrm{EB}$ was determined to be 41.58. CT value of pFMV gene in CRM DNA is 22.92; CT value in PK DNA was determined as 26.82 (Figure 1).

When the Turkish Food Codex, Baby Formula Communiqué [Communiqué No: 2014/31] is examined, when A, C, E, G and I coded samples are products called Baby Milk, when the Baby Continued Formula Communiqué [Communiqué No: 2014/32] is examined Samples with codes B, D, F, H and J appear to be so-called Baby Continued Milk. Since the total fat, carbohydrate and protein limits are given in the denominator of energy (100 kcal) in the communiqués, the measurement results are given over the energy while calculating. (Resmi Gazete, 2014a, Resmi Gazete, 2014b).

According to both communiqués, the energy value of the products should be 60 to $70 \mathrm{kcal} / 100 \mathrm{ml}$. When these values are examined, it is seen that the samples with $B$ $(70.3268 \pm 0.0323 \mathrm{kcal} / 100 \mathrm{ml})$ and $\mathrm{H}(70.1829 \pm 0.0526$ $\mathrm{kcal} / 100 \mathrm{ml}$ ) have energy values above the limits (Table 4). Considering the standard deviations of the analysis results, the calculated energy value for samples $\mathrm{B}$ and $\mathrm{H}$ coded is considered to be in line with the limits. It has been determined that the total fat results are compatible with the communiqué (Table 4). In the communiqué, protein limits are defined according to the source of the protein that the product contains. In the samples used in the study, $\mathrm{C}$ and $\mathrm{D}$ coded samples are classified as "Product produced from soy protein isolates alone or a mixture of soy protein isolates and cow's milk proteins". When Table 4 is examined, it is determined that A, B and C coded samples are below the limits in terms of protein content. Carbohydrate results are determined to be compatible with the communiqué.

Nassirpour et al. (2006) examined the combinations of baby formulas. The results obtained in the study are given in Table 6. When the results of this study and the current study (Table 4) are examined, it is determined that the nutritional values are generally parallel in terms of protein content, although the samples in the current study may appear to be low. 
Table 6. Nutritional values of baby milk and following milk products made from cow's milk (Nasirpour et al., 2006)

\begin{tabular}{l|cccc}
\hline \multirow{2}{*}{ Component } & \multicolumn{3}{c}{ Baby Milk } & \multicolumn{2}{c}{ Following Milk } \\
\cline { 2 - 5 } & Minimum & Maximum & Minimum & Maximum \\
\hline Energy $(\mathrm{kcal})$ & 600 & 800 & 600 & 800 \\
Protein $(\mathrm{g} / 100 \mathrm{~g})$ & 10.84 & 18.07 & 13.55 & 27.1 \\
Carbohydrate $(\mathrm{g} / 100 \mathrm{~g})$ & 42 & 84 & 42 & 84 \\
Fat $(\mathrm{g} / 100 \mathrm{~g})$ & 26.4 & 39 & 19.8 & 39 \\
\hline
\end{tabular}

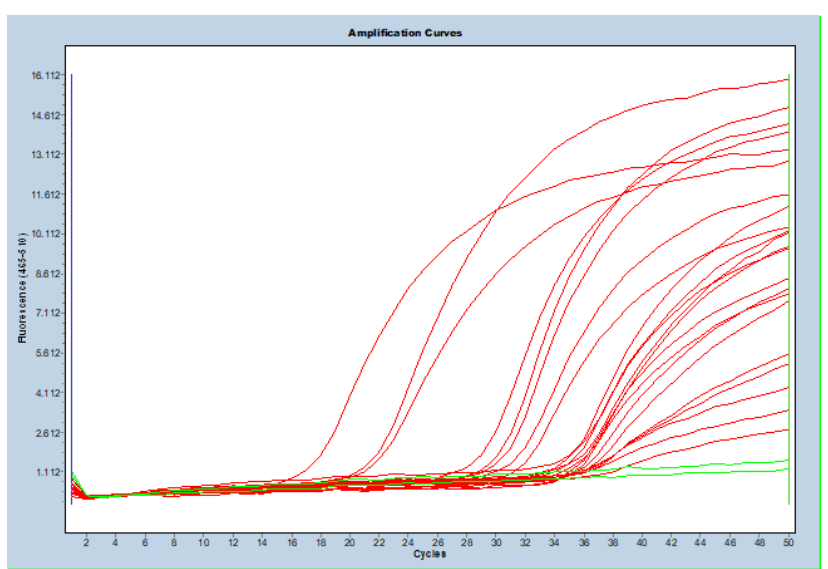

a

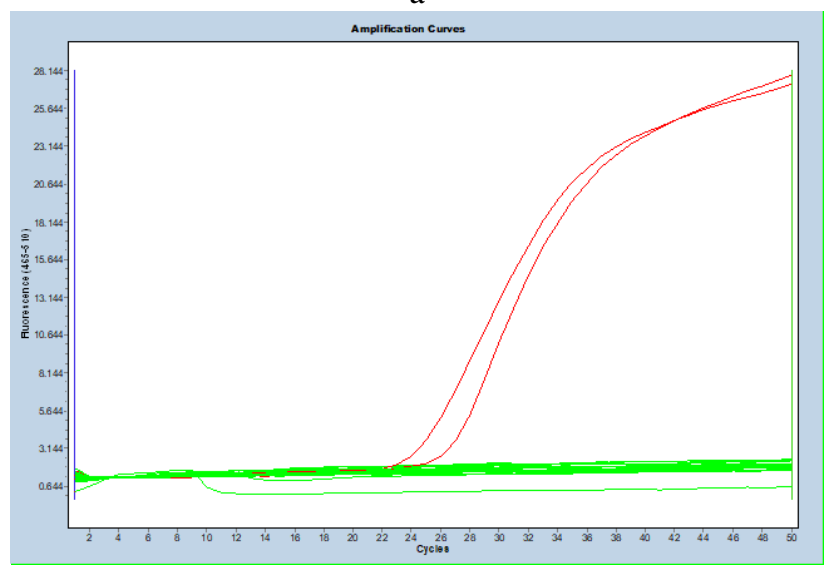

C

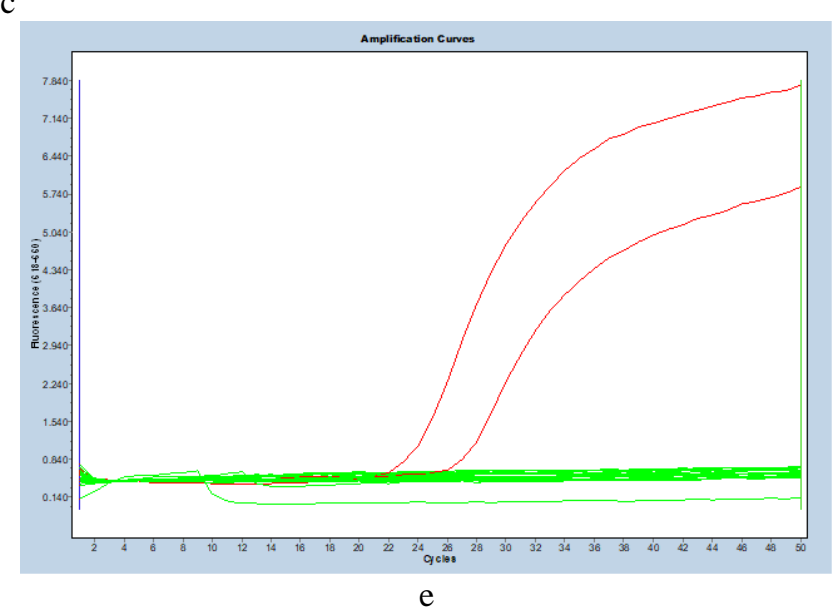

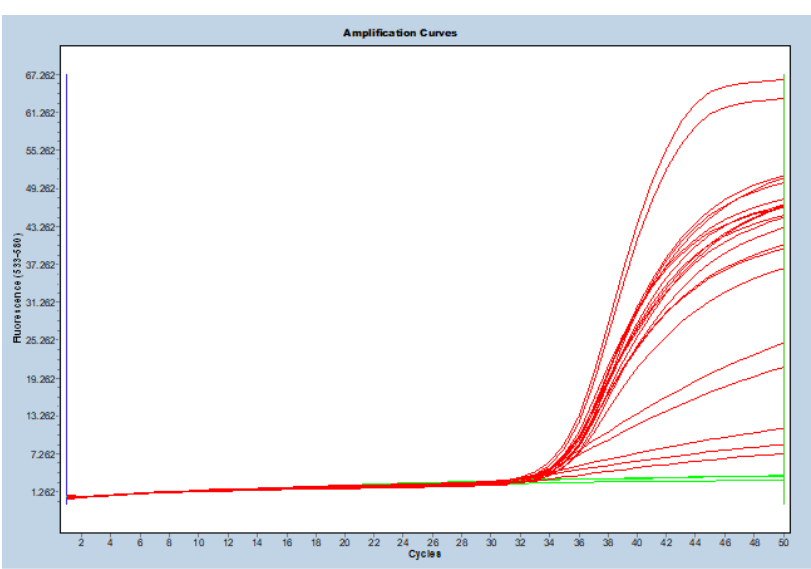

b

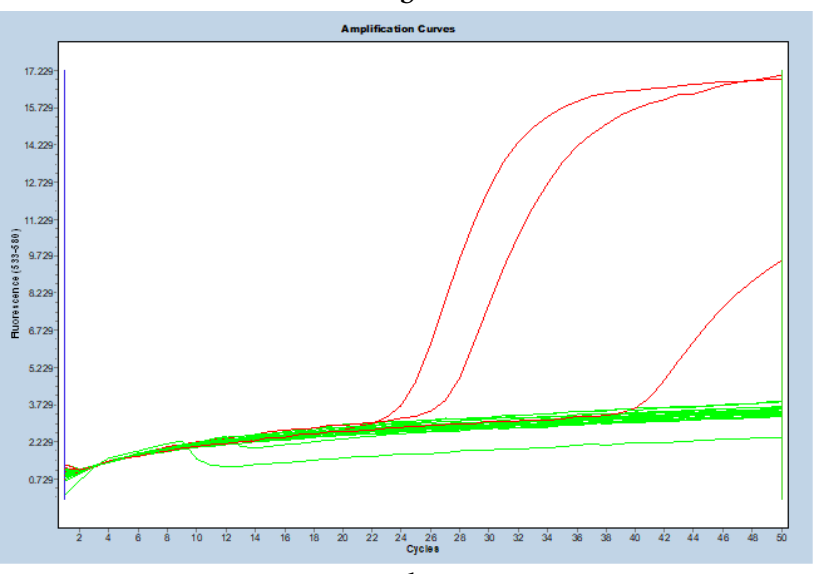

d

Figure 1. Amplification curves (a: Plant Genes, b: IC, c: p35S, d: tNOS, e: pFMV)

McCarthy and Gee's (2013) examined the effects of different storage conditions on the fat and protein values of infant formulas and they found that in products stored at $0 \%$ relative humidity for 14 days, the protein value was determined as $6.68 \pm 0.03$ and the amount of fat was 32.41 \pm 1.81 (McCarthy and Gee, 2013).
The concentration of nucleic acids was determined by measuring the absorbance at $260 \mathrm{~nm}$ against water. The presence of contaminants was distinguished by rate calculation. Since the proteins are absorbed at $260 \mathrm{~nm}$, the ratio of the absorbance value at $260 \mathrm{~nm}$ to the value at 280 $\mathrm{nm}$ is used to determine the purity of the nucleic acids. This 
ratio is expected to be between 1.8 and 2.0. However, in cases where the ratio cannot be achieved, it should be checked whether the plant gene is obtained by going to the PCR stage (Somma, 2006).

DNA concentration and DNA quality values of the samples are given in Table 5. According to the kit protocol used in Real Time PCR analysis, the DNA concentration to be loaded into the kit should be maximum $200 \mathrm{ng} / \mu \mathrm{L}$ (Biotecon, 2010). $5 \mu \mathrm{L}$ is taken from each DNA isolate during loading. Although it seems that the loading of the kit is above the capacity of the kit in B1 and B2 coded loads, it was determined that the kit works without any problem and there was amplication in the plant genes (Figure 1a).

In particular, during the isolation of DNA from processed herbal products, the inhibitory components (carbohydrates, proteins, phenolic components, fats, peptides, aromatic compounds etc.) contained in the product may not be eliminated. Therefore, there may be delays in CT value during Real Time PCR analysis when the DNA concentration is too low. (Ota and Lim, 2006; Elsanhoty et al., 2011; Somma, 2006).

In TS EN ISO 21569 "Analysis methods for the detection of genetically modified organisms and related products - Nucleic acid-based qualitative methods", the necessary control mechanisms for qualitative GMO analysis are defined. The EB, NK, CRM and IC controls were used in accordance with this standard. Amplification has been observed in plant genes. When the CT values of the IC control are examined (Table 5), it is seen that all samples except F1 and F2 have amplifiers. IC control is a control mechanism evaluated together with plant gene control. In cases where there is no plant gene amplification or when the plant gene is not isolated, the IC amplification is highest (Biotecon, 2010). In the study, the results were parallel to this control mechanism. No IC amplification was observed in F1 and F2 samples with the lowest CT value of the plant gene. In other instances, both controls showed amplification.

In this study, the target genes subjected to presence/absence analysis are p35S, tNOS and pFMV genes. No amplification in target genes was observed in the samples. In the "Prohibitions" section of the Regulation on Genetically Modified Organisms and Products, published in the Official Gazette dated 13.08.2010 and numbered 27671, "GMO and its products are prohibited to be used in baby foods and infant formulas, attendance formulas and attendance formulas and supplementary foods for infants and young children" [GMO products regulation]. For this reason, GMO screening results of the samples comply with the legislation.

When the amplification curves of the EB control were examined, a low level of contamination was observed in the tNOS gene region (Figure 1d). Since amplification for tNOS is not observed in the samples, it is thought that this amplification seen in the EB control should be evaluated as "false positive".

Brod and Ferrari (2007) screened baby formulas sold in Brazil to contain genetically modified soy. They isolated soybeans in baby formulas, but genetically modified soybeans was not detected.

Arun et al. (2013), in their study, they did not find p35S and tNOS genes in the screening of genetically modified soybeans and maize with PCR method on different baby food formula samples in Turkey.

Turkec et al. (2016), screened p35S, tNOS, pFMV, bar and GMO soybean on 10 follow-up formula samples in Turkey. As a result of the screening, no traces and GMO soy were found.

In this study, infant formula samples were screened for p35S, tNOS and pFMV trace genes and GMO products could not be detected in any of the samples. As a result, it can be said that the samples comply with GMO products regulations. Considering that it is allowed to produce GMOs without trace genes in recent years, it will be appropriate to use plant (plant specific) and species (eventspecies specific) screening analyzes in scientific researches.

\section{References}

Abdel-Salam Z, Sharnoubi, J A, Harith MA. 2013. Qualitative evaluation or maternal milk and commercial infant formulasvia LIBS. Talanta. 15: 422-432

Ahmed FE. 2002. Detection of Genetically Modified Organisms in Foods. TRENDS in Biotechnology. 20 (5): 215-223

Alpsan AF. 2008. Determination of available lysine and lactulose values in infant formulas. MSc Thesis. Ege University Graduate School of Natural and Applied Science. İzmir. Turkey

Alvarez E, Cancela A, Maceiras R. 2005. Rheological Behavior of Powdered Baby Foods. International Journal Of Food Properties. 8: 79-88

Anonymous (a). Baby Formula. Available from: http://www.madehow.com/Volume-4/Baby-Formula.html [Accessed 14 June 2013]

Anonymous (b). Genetically modified plants: Global cultivation on 174 million hectares. Available from: www.gmocompass.org/eng/agri_biotechnology/gmo_planting/257.glo bal_gm_planting_2013.html [Accessed 15 March 2014]

Anonymous (c). 2000. Crude Protein in Meat and Meat Products Including Pet Foods. AOAC Official Method 992.15

Arun ÖÖ, Yılmaz F, Muratoğlu K. 2013. PCR detection of genetically modified maize and soy in midly and highly processed foods. Food Control. 32: 525-531

Biotecon. 2010. Biotecon Diagnostics. Available from: https://www.bc-diagnostics.com/products/kits/real-timepcr/gmo/foodproof-gmo-screening-kit-4-targets/ [Accessed 15 March 2014]

Borchers A, Teuber S. 2010. Food Safety. Clinic Rev Allerg Immunol. 39: 95-141

Brod FCA, Ferrari CDS 2007. Nested PCR Detection of Genetically Modified Soybean in Soybean Flour, infant Formula and Soy Milk. LWT. 40: 748-751

Çelik V, Balık DT. 2007. Genetically Modified Organisms. Erciyes University Journal of The Institute of Science and Technology. 23: (1-2), 13-23

Elsanhoty R, Ramadan MF, Jany KD. 2011. DNA extraction methods for detecting genetically modified foods: A comparative study. Food Chemistry. 126: 1883-1889

Gaudio S, Cirillo A. 2010. A preamplification approach to GMO detection in processed foods. Anal Bioanal Chem. 396: 21352142

Gryson N. 2010. Effect of food processing on plant DNA degradation and PCR-based GMO analysis: a review. Anal Bioanal Chem. 396: 2003-2022

James C. Distribution of Biotech Crops in Industrial and Developing Countries. Available from: http://www.isaaa.org/ resources/publications/pocketk/16/default.asp [Accessed 30 November 2018] 
Kaya M, Karakoç Ş. 2010. Genetically Modified Organisms And Analysis Methods. Journal of NFRL. 1 (1): 21-29

Kıran F, Osmanağaoğlu Ö. 2011. Detection of Genetically Modified Organisms (GMOs) in Food. Gida. 36 (5): 295-302

Kulaç İ, Ağırdil Y. 2006. The Sweet Trouble on Our Tables, Genetically Modified Organisms and Their Effects on Public Health. Turkish Journal of Biochemistry. 31(3): 151-155

Li H, Zhu K. 2011. Effects of High Hydrostatic Pressure on Some Functional and Nutritional Properties of Soy Protein Isolate for Infant Formula. J. Agric. Food Chem. 59: 12028-12036

McCarthy NA, Gee LV. 2013. Effect of protein content on the physical stability and microstructure of a model infant formula. International Dairy Journal. 29: 53-59

Morales V, Olano A. 2004. Ratio of Maltose To Maltulose and Furosine as Quality Parameters for Infant Formula. J. Agric. Food Chem. 52: 6732-6736

Nardal1 S, Kartal B. 2005. Looking at the genetically modified organisms (GMO) issue from the aspects of consumer protection and agricultural productivity. Celal Bayar University Journal. 6 (24): 183-195

Nasirpour A, Scher J, Desorby S. 2006. Baby Foods: Formulations and Interactions A Review. Critical Reviews in Food Science and Nutrition. 46: 665-681

Ota H, Lim T. 2006. Automated DNA extraction from genetically modified maize using aminosilane-modified bacterial magnetic particles. Journal of Biotechnology. 125: 361-368

Özdemir O, Duran M. 2010. Consumer attitude towards biotechnological applications and genetically modified organisms. Academic Food Journal. 8 (5): 20-28
Park KW, Lee B. 2010. Monitoring The Occurrence of Genetically Modified Maize at Grain Receiving Port and Along Transportation Routes in the Republic of Korea. Food Control. 21: 456-461

Turkish Official Newspaper (a) 2014. Infant Formulas Communique. 2014/31

Turkish Official Newspaper (b) 2014. Communique on Continuation Formulas. 2014/32

Roche. 2010. Roche Life Science. Available from: https://lifescience.roche.com/en_tr/products/magna-purecompact-nucleic-acid-isolation-kit-i.html [Accessed 15 March 2014]

Somma M. 2006. DNA extraction and purification. In: Querci, M., Jermini, M., Eede, G. V. (editors). The Analysis of Food Samples fort he Presence of Genetically Modified Organisms. Publications Office of the European Union. pp. 39. ISBN: 978-92-76-17349-6 (print)

TS 11729. Baby Food Analysis Methods - Carbohydrate Determination. Turkish Standarts Institution. 1995

TS 1511. Cereals and Milled Cereal Products - Determination of Total Ash Content. Turkish Standarts Institution. 2000

TS 4967. Determination of Total Fat Content of Cereals and Cereal Products. Turkish Standarts Institution. 1986

Turkec A, Lucas JS, Karlık E. 2016. Monitoring the prevalence of genetically modified GM soybean in Turkish food and feed products. Food Control. 59: 766-772

Turkish Food Codex. 2011. Labeling Regulation Official Newspaper No: 29.12.2011/28157. Available from: https://www.resmigazete.gov.tr/eskiler/2011/12/20111229M 3-7.htm [Accessed 12 February 2016] 